\author{
MONIKA KuŹMiCZ \\ Cezary Ortowski 1 \\ BARTOSZ BOBER
}

\title{
CASE STUDY OF PROJECT MANAGEMENT IN DISTRICT COURT
}

\begin{abstract}
The aim of this article is to present the project environment for the implementation of an IT system in a district court as well as an analysis of the entities and processes on the basis of which this model was built. It includes all of the identified processes that have been assigned responsible entities and the artifacts arising as a result of these processes. The analysis and identification of the processes, entities, and artifacts was carried out on the basis of the realized project of customizing and implementing an IT system. The customization involves the parameterization and adjustment of a standard solution to the needs of a specific recipient 18; in this case, to the needs of a district court. This case study is part of the research in the area of project management in the common courts for the needs of doctoral dissertations. The methodology of this research is presented in the third chapter.
\end{abstract}

Keywords

IT system, IT project, IT project management, common courts, case study, case-based reasoning, district court

Citation Computer Science 19(4) 2018: 361-384 


\section{Introduction}

This article is a continuation of the conceptual article on IT project management in the common courts of Poland [6]. The authors posed a question about key problems in this area. Following this, their identification was made, where it was pointed out, among others, the little experience of court employees in the implementation of IT initiatives, varied levels of organizational and project maturity of the courts, lack of good practices regarding project management in the judiciary, "stretching" scope of the implemented initiatives, lack of communication in the project, unawareness of the requirements in the initial stages of the project, and changing of legal regulations, all of which directly affect the scope or necessity of creating exhaustive documentation before starting the tender.

Having knowledge about significant problems, the authors posed another question about the key entities and processes in the context of implementing projects in the common courts of Poland and hypothesized that there is a need to build a project framework to implement these IT initiatives. Therefore, it is reasonable to build a model that will improve the management of IT projects in the judiciary, which is the direct aim of this research. In addition, delivering the knowledge for common courts on the main problems during the implementation of IT projects and providing models covering the entities and processes that facilitate the implementation of IT projects in common courts is a utilitarian purpose.

In the previous article, it was pointed out that the entities and processes are crucial for the implementation of these projects in the common courts. Hence, the authors of this article decided to focus on these key elements of the project. This publication focuses primarily on the entities and processes involved with project management, which was realized in one of the district courts in central Poland. The second chapter presents the available approaches and methods in the field of project management, and this state was embedded in the judicial environment in the third chapter. The fourth chapter contains a description of the case of project implementation management of an IT system in a district court. Two subsections include the identified entities and the relationships between them as well as the identified processes.

This case study was created based on an analysis of the project documentation and the experience of the authors. In this chapter, the project environment is presented (primarily, the project goal). The authors define the project environment as a set of internal and external occurrences, processes, institutions, groups, and entities that effect the project or are under the project's influence (the project's effects on them) [17]. This section also includes the scope of the project and the justification for the business value and its location in the court environment.

The fifth chapter includes a description of the methodology and research as well as embedding the case study in this research; it also contains the model. The last chapter presents a summary of the realized works, a description of the successes and failures of this project, and our conclusions along with the next steps of the research. 


\section{Existing methods (approaches) of IT project management}

We have seen dynamic development in the field of project management over the last 20 years. This is directly related to the ever-growing demand for IT solutions in practically every area of the economy. Although the beginnings of project management were already being observed during World War II in the military industry (the Manhattan project, whose aim was to build an atomic bomb), it was adopted by all other areas of life in subsequent years, especially in the field of information technology. Nowadays, it is difficult to imagine any sector without a project approach, from the worlds of finance or science to culture or sport [15]. Despite the fact that the beginning of project management took place several decades ago, systematizing this knowledge began only about 20 years ago. As a result of this, many approaches, concepts, and methodologies for project management have arisen. Currently, we have two main approaches to running projects: a heavy (classic, traditional) approach, and a light (agile) approach [13].

The first approach was the approach to project management, which is now called the classic approach. Such an approach is characterized by defining in advance the entire scope of a project and plan (schedule) as well as their constancy. The goal of the project is to provide a product with predefined requirements. In addition, the delivery of the assumed product is interpreted as the success of the project. This approach is also characterized by a certain way of working with a client who has a very limited ability to interfere with the project during its lifetime. In addition, sequential-cascade models of product implementation are used in the classical approach [7].

Among the traditional approach to project management, three main standards and methodologies can be distinguished: the PMBOK standard (created by Project Management Institute - PMI), the Prince2 methodology, and the IPMA approach (International Project Management Association). Prince2 is a methodology characterized by a process approach to project management based on seven principles, seven topics, and seven processes. In turn, PMBOK is a collection of good practices based on experience, the purpose of which is to provide guidance for the implemented initiatives. Similarly, IPMA is a set of guidelines and recommendations that provide project managers with a high level of competence (behavioral, contextual, and technical) [7].

Undoubtedly, the strength of this approach is defining and knowing all of the requirements as well as the schedule at the beginning of a project and the fact that high competencies and experience are not required by team members (the methodologies provide detailed information). On the other hand, among the weaknesses, one can point to a limited possibility of introducing changes, which may result in the dissatisfaction of a customer with a delivered product (often, the customer is not aware of his needs at the beginning of the project) or a large amount of project documentation [15].

In recent years, the approach to project management has changed; this has resulted in the creation of the agile approach. This approach is characterized by a focus on customer needs and providing business value (in the case of the classic approach, it is said about delivering products) through close cooperation with the client throughout the entire duration of the project. In addition, this approach is often defined as an 
adaptive approach to the implementation of the project due to the possibility to change its scope. In the case of software development, an iterative-incremental approach is preferred. Another difference is the manner of team member cooperation (who now have much greater freedom) and where the responsibilities and decision-making are scattered. Among the fundamental differences, there should also be a minimalist approach to producing documentation and defining general fluid schedules [8].

The agile approach has been improved very dynamically recently, which results in the creation of many methodologies or frameworks in this area. This approach can be distinguished by the AgilePM methodology, Scrum framework, Scrumban software production model, Extreme Programming methodology, and Crystal Clear methodology [7]. The advantages of an agile approach are primarily the focus on customer needs and satisfaction as well as flexibility in defining the scope or frequent delivery of a part of the system. On the other hand, among its weaknesses, it should be pointed out that this approach works rather in mature teams due to the scattered decision-making of team members as well as the need for multitasking.

Choosing the right project management approach is key to achieving the goals of a project. In addition, among the potential benefits of effective project management, we can point to the clear identification of responsibility to account for activities regardless of personnel changes in the project, minimizing reporting needs; this will save time, help identify of time limits in the schedule, allow for the early identification of problems, and improve the accuracy of estimates when creating subsequent plans [5]. The next chapter presents the state of knowledge of project management in the court environment. In addition, the limitations of the use of the currently available methods are presented.

\section{State of knowledge of IT project management in common courts}

The substantiation for building an IT project management model embedding the problem in the current state of knowledge is presented in Zarzadzanie projektami informatycznymi w jednostkach sadownictwa powszechnego w Polsce [6]. This article reviews the available methodologies and identifies the main problems accompanying the implementation of projects in the area of the judiciary. The limitations on the use of available approaches are then indicated.

In the case of the classical project management approach, the main problems were the limited experience of the members of initiatives on the side of the courts and often changing legal regulations, which caused a change in the scope of the project. On the other hand, the requirement for a comprehensive and exhausting definition of the scope of the project (often at the stage of the tender) significantly limits the possibility of using the agile approach. In addition, the authors point to the legitimacy of creating a hybrid model that would allow for the maintenance of the classic approach at a higher level and introducing agility in the lower levels, along with embedding the model in a specific court environment. Another big limitation of both of the available 
approaches is the way of defining the organizational structure, which does not allow us to reflect the units and entities involved in the implementation of projects. In other words, the embedding of the project structure in the organizational structure and the inclusion of business, organizational, and design relationships requires an individual approach dedicated solely to the court environment.

Next, the authors reviewed the available state of knowledge applied to the court. The article also reviews the available state of knowledge in this area. As a result, it was found only the good practices of "IT Resource Management and Services" posted by the Ministry of Justice and published in 2016 [9], which are based on ITIL (Information Technology Infrastructure Library). In the context of project implementation, only one practice was indicated, which recommended a process approach to the implementation of initiatives.

Moreover, until now, the main motive of a project in the public sector was profit, which was settled at the completion of the project. At present, there are also other benefits arising from efficient project implementation, which is why the experience of organizations and entities implementing the project is becoming more and more important. That is why many organizations gain knowledge and appoint a project manager from external companies. In Poland, such an approach can be found in the private sector, while this is very rare in the public sector. In addition, available project management approaches are used by the public sector where projects are more complex, making management more difficult and demanding. So, these approaches do not fully correspond to the needs. The main problems for this sector are various: conflicting goals of the entities involved in the project, a lower tolerance for failures, emerging opponents of the project, the project goals may conflict with the existing habits of the entities, the need for cooperation with entities outside the project team, implementation under constraints imposed by administrative rules, or processes that may delay the projects [5].

The available literature concerns the public sector, but it is not strictly applied to the judiciary. In addition, the authors focus on a common judiciary in Poland, which further limits the use of the available literature. What is more, the specificity of the court structure in Poland, legal regulations, and following the specific project environment make it impossible to use international literature. Taking into account the indicated gap, it is justified to build a dedicated project management model for the judiciary that will take into account the specific conditions of the judicial environment and, as a consequence, will help streamline the implementation of the IT initiatives. The next chapter presents a description of the project management case study.

\section{Description of project management case implementation of IT system}

The subject of this case study is the project of deploying and customizing the Business Intelligence (BI) class system to the needs of the district court. BI class systems 
are dynamically developing systems of decision support [1]. The purpose of these systems is to collect data from various sources, deposit it to the data warehouse, and process it in providing information and knowledge. In the case of the judiciary, such systems are particularly useful because they collect data from all of the jurisprudence departments in one place. It should be noted that each department uses a different application that is specific due to the different expert activity in each department. Hence, each statistical indicator (e.g., the number of cases that have been registered in a department) can be calculated in a different way in each department. Owing to the implementation of data-processing mechanisms (including a defined data range), these systems provide ad-hoc transparent information for decision support.

Common courts are obligated to report on current activities for different time periods; e.g., the past month, quarter, half year, or year. This obligation is not only periodic and regular but also casual (ad-hoc), both in terms of the reporting period and the scope of the reported data. It should also be noted that the order for the preparation of such a report may fall from various institutions; for example, from the supervising court (this means from the appellate court to a regional court or the regional court to a district court) or directly from the Ministry of Justice. An example of regular reporting to which all common courts are obligated are ministerial statistics. The scope of the data is specific to each faculty and instance and is subject to frequent changes as related to the previous reporting period.

The purpose of the project was to provide solutions that included the implementation of a data warehouse including the extraction, transformation, and loading of data (ETLs) from departmental databases to the data warehouse and the presentation layer of the data as illustrated in the figure below (Fig. 1). The warehouse is pulled data out of the departmental system databases at defined intervals. As far as the presentation layer is concerned, a standard set of reports has been defined. In order to further increasing the business value, an analysis of the reporting needs was carried out and a new report implemented. This report covers the need for quarterly reports to the supervisory (regional) court. In addition to the set of reports, the solution included a tool for creating a multidimensional analysis of the collected data.

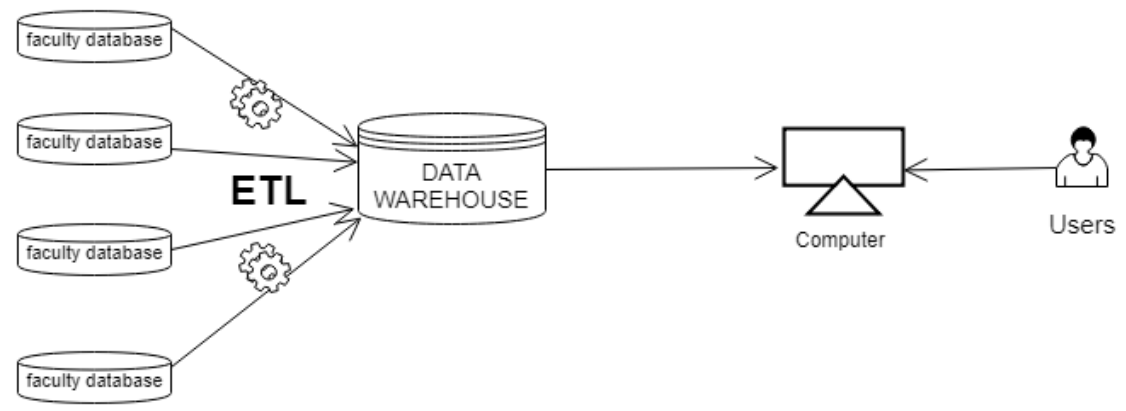

Figure 1. Architecture of implemented solution in district court 


\subsection{Case study - identification of project entities}

This chapter is dedicated to identifying and analyzing the entities as well as the relationships between them. The authors define the project entity as a unit directly involved in the project. The organizational structure of the project entities and the project structure are presented in a further part of the chapter. The last part of this chapter contains a diagram of the project structure in the organizational structure.

The first part of the chapter is focused on the organizational structure. The authors tried to use a way of defining the project structure from the available methodologies. Here, the high-level approach included in Prince2 was the closest. Nevertheless, to reflect the structure, a definition of the entity pool has been introduced that represents a set of entities within one organizational unit. The analyzed project identified three pools of entities: the district court, regional court, and IT service provider. The following table contains the identified entities (Tab. 1). Each entity was assigned to the pool, and a brief description was added.

Table 1

Organizational structure of entities involved in project

\begin{tabular}{|c|l|l|l|}
\hline N & $\begin{array}{l}\text { Entities } \\
\text { pool }\end{array}$ & \multicolumn{1}{|c|}{ Entity } & \multicolumn{1}{|c|}{ Description } \\
\hline 1. & $\begin{array}{l}\text { IT } \\
\text { service } \\
\text { provider }\end{array}$ & Management & Team driving the organization \\
\hline 2. & $\begin{array}{l}\text { IT } \\
\text { service } \\
\text { provider }\end{array}$ & $\begin{array}{l}\text { Software } \\
\text { Development } \\
\text { Department }\end{array}$ & $\begin{array}{l}\text { Department responsible for programming and } \\
\text { maintenance of software }\end{array}$ \\
\hline 3. & $\begin{array}{l}\text { IT } \\
\text { service } \\
\text { provider }\end{array}$ & $\begin{array}{l}\text { Project } \\
\text { Management } \\
\text { Office }\end{array}$ & $\begin{array}{l}\text { Unit aimed at the implementation of projects in the } \\
\text { organization }\end{array}$ \\
\hline 4. & $\begin{array}{l}\text { IT } \\
\text { service } \\
\text { provider }\end{array}$ & $\begin{array}{l}\text { Analysis } \\
\text { Team }\end{array}$ & $\begin{array}{l}\text { Team of business-system analysts responsible for } \\
\text { planning and developing solution architectures and } \\
\text { defining and analyzing requirements }\end{array}$ \\
\hline 5. & $\begin{array}{l}\text { IT } \\
\text { service } \\
\text { provider }\end{array}$ & $\begin{array}{l}\text { Programmer } \\
\text { Team }\end{array}$ & $\begin{array}{l}\text { Team of programmers responsible for implementing } \\
\text { defined requirements. Here are also ETL programmers } \\
\text { and data warehouses and reports }\end{array}$ \\
\hline 6. & $\begin{array}{l}\text { IT } \\
\text { service } \\
\text { provider }\end{array}$ & $\begin{array}{l}\text { Tester Team } \\
\text { IT } \\
\text { service } \\
\text { provider }\end{array}$ & $\begin{array}{l}\text { Team responsible for quality assurance, also in the } \\
\text { field of data processing as well as verification of } \\
\text { measurements in the presentation layer }\end{array}$ \\
\hline 7. & $\begin{array}{l}\text { Team responsible for installation and parameterization } \\
\text { of software deployed }\end{array}$ \\
\hline
\end{tabular}


Table 1 (cont.)

\begin{tabular}{|c|c|c|c|}
\hline $\mathrm{N}$ & $\begin{array}{c}\text { Entities } \\
\text { pool }\end{array}$ & Entity & Description \\
\hline 8. & $\begin{array}{l}\text { IT } \\
\text { service } \\
\text { provider }\end{array}$ & Trainer team & $\begin{array}{l}\text { Team responsible for preparing training materials and } \\
\text { conducting training }\end{array}$ \\
\hline 9. & $\begin{array}{l}\text { District } \\
\text { court }\end{array}$ & President & $\begin{array}{l}\text { He directs the court and represents the court outside, } \\
\text { except for matters falling within the competence of the } \\
\text { court director [11]. He exercises direct supervision over } \\
\text { the substantive and administrative activity of the court }\end{array}$ \\
\hline 10. & $\begin{array}{l}\text { District } \\
\text { court }\end{array}$ & Director & He directs the administrative activities of the court \\
\hline 11. & $\begin{array}{l}\text { District } \\
\text { court }\end{array}$ & $\begin{array}{l}\text { IT } \\
\text { Department }\end{array}$ & $\begin{array}{l}\text { Supervision and implementation of investment projects } \\
\text { related to projects requiring the use of information } \\
\text { technology, support, and advice to other entities in the } \\
\text { field of the used technologies }\end{array}$ \\
\hline 12. & $\begin{array}{l}\text { District } \\
\text { court }\end{array}$ & $\begin{array}{l}\text { Administrative } \\
\text { department }\end{array}$ & $\begin{array}{l}\text { Running the secretariat of the president, vice president, } \\
\text { and improving the organization and technique of the } \\
\text { secretariats. In addition, coordinating and supervising } \\
\text { court administrative activities and staff matters }\end{array}$ \\
\hline 13. & $\begin{array}{l}\text { District } \\
\text { court }\end{array}$ & $\begin{array}{l}\text { Court } \\
\text { departments } \\
(\mathrm{I}, \mathrm{II}, \mathrm{III}, \mathrm{IV})\end{array}$ & $\begin{array}{l}\text { Maintaining and record-keeping case, specific to the } \\
\text { department, reporting }\end{array}$ \\
\hline 14. & $\begin{array}{l}\text { Regional } \\
\text { court }\end{array}$ & President & Same as in the case of the district court \\
\hline 15. & $\begin{array}{l}\text { Regional } \\
\text { court }\end{array}$ & Director & Same as in the case of the district court \\
\hline 16. & $\begin{array}{l}\text { Regional } \\
\text { court }\end{array}$ & $\begin{array}{l}\text { IT } \\
\text { Department }\end{array}$ & Same as in the case of the district court \\
\hline 17. & $\begin{array}{l}\text { Regional } \\
\text { court }\end{array}$ & $\begin{array}{l}\text { Administrative } \\
\text { department }\end{array}$ & $\begin{array}{l}\text { Running the secretariat of the president, vice president, } \\
\text { and improving the organization and technique of the } \\
\text { secretariats. In addition, coordinating and supervising } \\
\text { court administrative activities }\end{array}$ \\
\hline 18. & $\begin{array}{l}\text { Regional } \\
\text { court }\end{array}$ & $\begin{array}{l}\text { Financial } \\
\text { Department }\end{array}$ & Financial and staff matters \\
\hline 19. & $\begin{array}{l}\text { Regional } \\
\text { court }\end{array}$ & $\begin{array}{l}\text { Analytical } \\
\text { Department }\end{array}$ & Keeping reporting \\
\hline 20. & $\begin{array}{l}\text { Regional } \\
\text { court }\end{array}$ & $\begin{array}{l}\text { Court } \\
\text { departments } \\
(\mathrm{I}, \mathrm{II}, \mathrm{III}, \mathrm{IV}, \\
\text { V, VI, VII, } \\
\text { VIII, IX, X) }\end{array}$ & $\begin{array}{l}\text { Maintaining and record-keeping case, specific to the } \\
\text { department }\end{array}$ \\
\hline
\end{tabular}


In the next step, two types of relationships were identified between the above entities: business and organizational (to show the relationships between the entities outside the project structure). An organizational relationship occurs between entities within a single pool and between the district and regional courts.

The regional court oversees the district court on the basis of legal regulations. In turn, there is a business relationship between an IT service provider and a district court based on a licensing and implementation agreement. In other words, the district court orders a specific service, which the supplier then implements. The following figure (Fig. 2) shows the identified entities and relationships in the organizational structure.
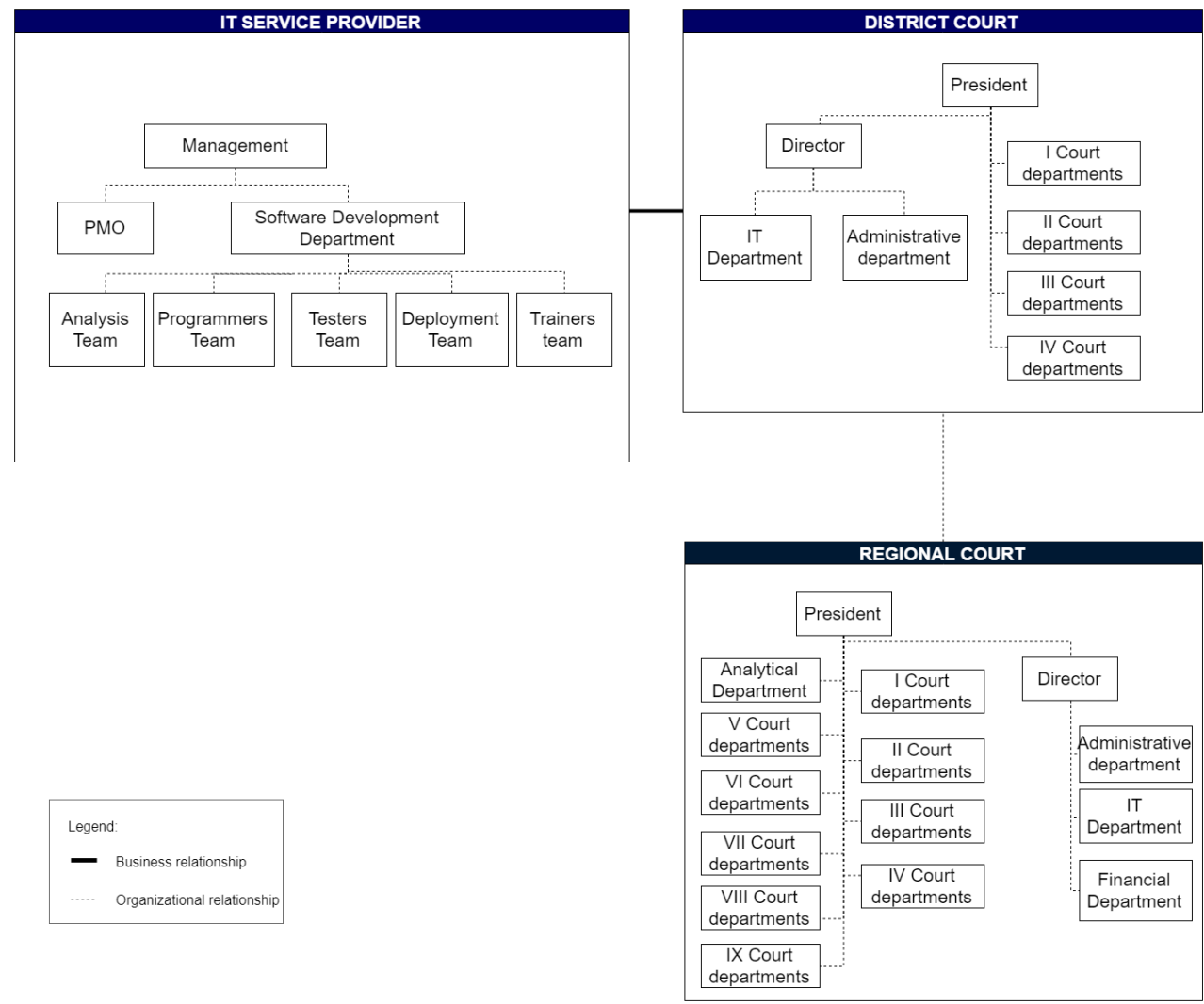

Figure 2. Organizational structure of entities involved in project

In the next part of the chapter is a presentation of the project structure of the entities together with their relationships. The description and responsibilities of each of the entities are included in the table below (Tab. 2). 


\section{Table 2}

Project structure

\begin{tabular}{|c|l|l|}
\hline $\mathrm{N}$ & \multicolumn{1}{|c|}{ Entity } & \multicolumn{1}{c|}{ Description } \\
\hline 1. & Steering Committee & $\begin{array}{l}\text { Strategic management of the project, making key } \\
\text { decisions, general supervision }\end{array}$ \\
\hline 2. & Project Manager & $\begin{array}{l}\text { Operational management of the project, creation } \\
\text { of work plans, supervision of entrusted tasks and } \\
\text { progress control, project status reporting }\end{array}$ \\
\hline 3. & Analyst & Defining and analyzing system requirements \\
\hline 4. & Programmer & Programming of the solution \\
\hline 5. & Tester & \begin{tabular}{l} 
Ensuring system quality \\
\hline 6.
\end{tabular} Implementation \\
\hline 7. & $\begin{array}{l}\text { Substantive } \\
\text { consultant }\end{array}$ & $\begin{array}{l}\text { Installation and parameterization of the software } \\
\text { deployed, preparing data }\end{array}$ \\
\hline 8. & Trainer & $\begin{array}{l}\text { Collaboration in the analysis of reporting needs } \\
\text { materials }\end{array}$ \\
\hline
\end{tabular}

The identified entities are presented in the figure below (Fig. 3). The project relationship has been defined within these entities.

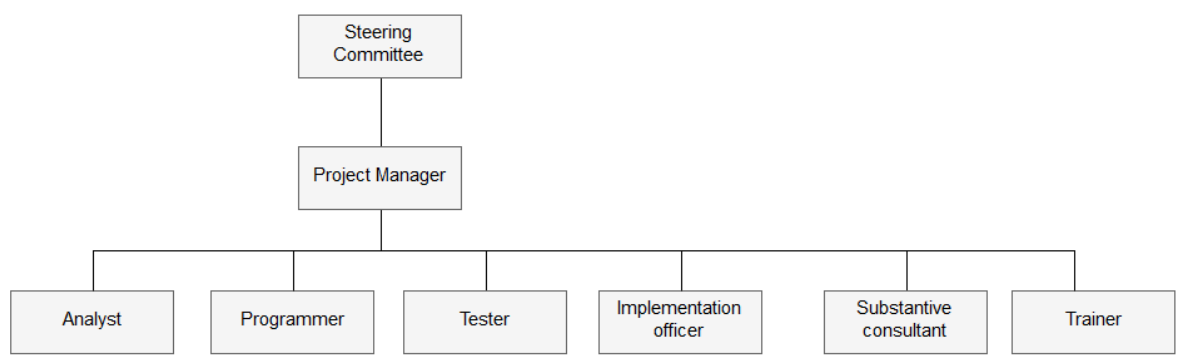

Legend:

- Project relationship

Figure 3. Project structure

The last part of this chapter shows the structure of the project in the perspective of the organizational structure. The following table (Tab. 3) includes the identified entities (including assignment to the pool) and a description of the role in the project. The figure below (Fig. 4) presents the project structure entities imposed on the organizational structure to present key entities outside the entities pool where the project was implemented. 
Table 3

Project structure in organizational structure

\begin{tabular}{|c|c|c|c|c|}
\hline $\mathrm{N}$ & $\begin{array}{l}\text { Entity in } \\
\text { the project } \\
\text { structure }\end{array}$ & $\begin{array}{c}\text { Entities } \\
\text { pool }\end{array}$ & $\begin{array}{c}\text { Entity in the } \\
\text { organizational } \\
\text { structure }\end{array}$ & Description/Responsibility \\
\hline 1. & $\begin{array}{l}\text { Steering } \\
\text { Committee }\end{array}$ & $\begin{array}{l}\text { IT service } \\
\text { provider }\end{array}$ & Management & $\begin{array}{l}\text { Presentation of the solution, contract } \\
\text { negotiations, appointment of the } \\
\text { project manager, project supervision }\end{array}$ \\
\hline 2. & $\begin{array}{l}\text { Steering } \\
\text { Committee }\end{array}$ & $\begin{array}{l}\text { District } \\
\text { court }\end{array}$ & Director & $\begin{array}{l}\text { Signing the contract, commission } \\
\text { to start the project, signing the } \\
\text { acceptance protocol }\end{array}$ \\
\hline 3. & $\begin{array}{l}\text { Project } \\
\text { Manager }\end{array}$ & $\begin{array}{l}\text { IT service } \\
\text { provider }\end{array}$ & PMO & $\begin{array}{l}\text { Initiation of the project, } \\
\text { preparation of the Project Initiating } \\
\text { Documentation, communication } \\
\text { management also on the client } \\
\text { side, planning and organization of } \\
\text { the work also on the client side, } \\
\text { supervision of the work, progress } \\
\text { reporting, project scope management, } \\
\text { risk management, preparation and } \\
\text { signing of the acceptance protocol }\end{array}$ \\
\hline 4. & Analyst & $\begin{array}{l}\text { IT service } \\
\text { provider }\end{array}$ & $\begin{array}{l}\text { Analysis } \\
\text { Team }\end{array}$ & $\begin{array}{l}\text { Analysis of reporting requirements, } \\
\text { construction of algorithms for } \\
\text { calculating measures, analysis of } \\
\text { source systems }\end{array}$ \\
\hline 5. & Analyst & $\begin{array}{l}\text { Regional } \\
\text { court }\end{array}$ & $\begin{array}{l}\text { Analytical } \\
\text { Department }\end{array}$ & $\begin{array}{l}\text { Role outside the project, not directly } \\
\text { involved in the project. In the } \\
\text { regional court are defined report } \\
\text { requirements that are then passed } \\
\text { on to the district courts }\end{array}$ \\
\hline 6. & Programmer & $\begin{array}{l}\text { IT service } \\
\text { provider }\end{array}$ & $\begin{array}{l}\text { Programmer } \\
\text { Team }\end{array}$ & $\begin{array}{l}\text { Implementation of requirements, } \\
\text { Data Warehouse, ETL mechanisms, } \\
\text { as well as their maintenance, creation } \\
\text { of reports }\end{array}$ \\
\hline 7. & Tester & $\begin{array}{l}\text { IT service } \\
\text { provider }\end{array}$ & Tester Team & $\begin{array}{l}\text { Ensuring system quality, verification } \\
\text { of processing (ETL tests) as well as } \\
\text { reports, acceptance tests }\end{array}$ \\
\hline 8. & Tester & $\begin{array}{l}\text { District } \\
\text { court }\end{array}$ & $\begin{array}{l}\text { Court } \\
\text { departments } \\
(\mathrm{I}, \mathrm{II}, \mathrm{III}, \mathrm{IV})\end{array}$ & $\begin{array}{l}\text { Verification of conformity of } \\
\text { measurement values; acceptance } \\
\text { testing }\end{array}$ \\
\hline 9. & $\begin{array}{l}\text { Implemen- } \\
\text { tation } \\
\text { officer }\end{array}$ & $\begin{array}{l}\text { District } \\
\text { court }\end{array}$ & $\begin{array}{l}\text { IT } \\
\text { Department }\end{array}$ & $\begin{array}{l}\text { Server preparation, access to } \\
\text { infrastructure during deployment, } \\
\text { infrastructure preparation for } \\
\text { training }\end{array}$ \\
\hline
\end{tabular}


Table 3 (cont.)

\begin{tabular}{|c|c|c|c|c|}
\hline $\mathrm{N}$ & $\begin{array}{l}\text { Entity in } \\
\text { the project } \\
\text { structure }\end{array}$ & $\begin{array}{l}\text { Entities } \\
\text { pool }\end{array}$ & $\begin{array}{l}\text { Entity in the } \\
\text { organizational } \\
\text { structure }\end{array}$ & Description/Responsibility \\
\hline 10. & $\begin{array}{l}\text { Implemen- } \\
\text { tation } \\
\text { officer }\end{array}$ & $\begin{array}{l}\text { IT service } \\
\text { provider }\end{array}$ & $\begin{array}{l}\text { Deployment } \\
\text { Team }\end{array}$ & $\begin{array}{l}\text { Installation of the solution, } \\
\text { preparation of correctness reports } \\
\text { indicating irregularities in the source } \\
\text { data, initialization of the data } \\
\text { warehouse, parameterization of the } \\
\text { solution, launch of the initial pulling }\end{array}$ \\
\hline 11. & $\begin{array}{l}\text { Implemen- } \\
\text { tation } \\
\text { officer }\end{array}$ & $\begin{array}{l}\text { District } \\
\text { court }\end{array}$ & $\begin{array}{l}\text { Court } \\
\text { departments } \\
(\mathrm{I}, \mathrm{II}, \mathrm{III}, \mathrm{IV})\end{array}$ & $\begin{array}{l}\text { Preparation and correcting the } \\
\text { data that was indicated in the data } \\
\text { correctness reports }\end{array}$ \\
\hline 12. & $\begin{array}{l}\text { Substantive } \\
\text { consultant }\end{array}$ & $\begin{array}{l}\text { District } \\
\text { court }\end{array}$ & $\begin{array}{l}\text { Court } \\
\text { departments } \\
(\mathrm{I}, \mathrm{II}, \mathrm{III}, \mathrm{IV}) \\
\end{array}$ & $\begin{array}{l}\text { Refine reporting requirements, } \\
\text { support for defining algorithms for } \\
\text { calculating measures on a report }\end{array}$ \\
\hline 13. & Trainer & $\begin{array}{l}\text { IT service } \\
\text { provider }\end{array}$ & Trainer team & $\begin{array}{l}\text { Training, preparation of training } \\
\text { materials }\end{array}$ \\
\hline
\end{tabular}
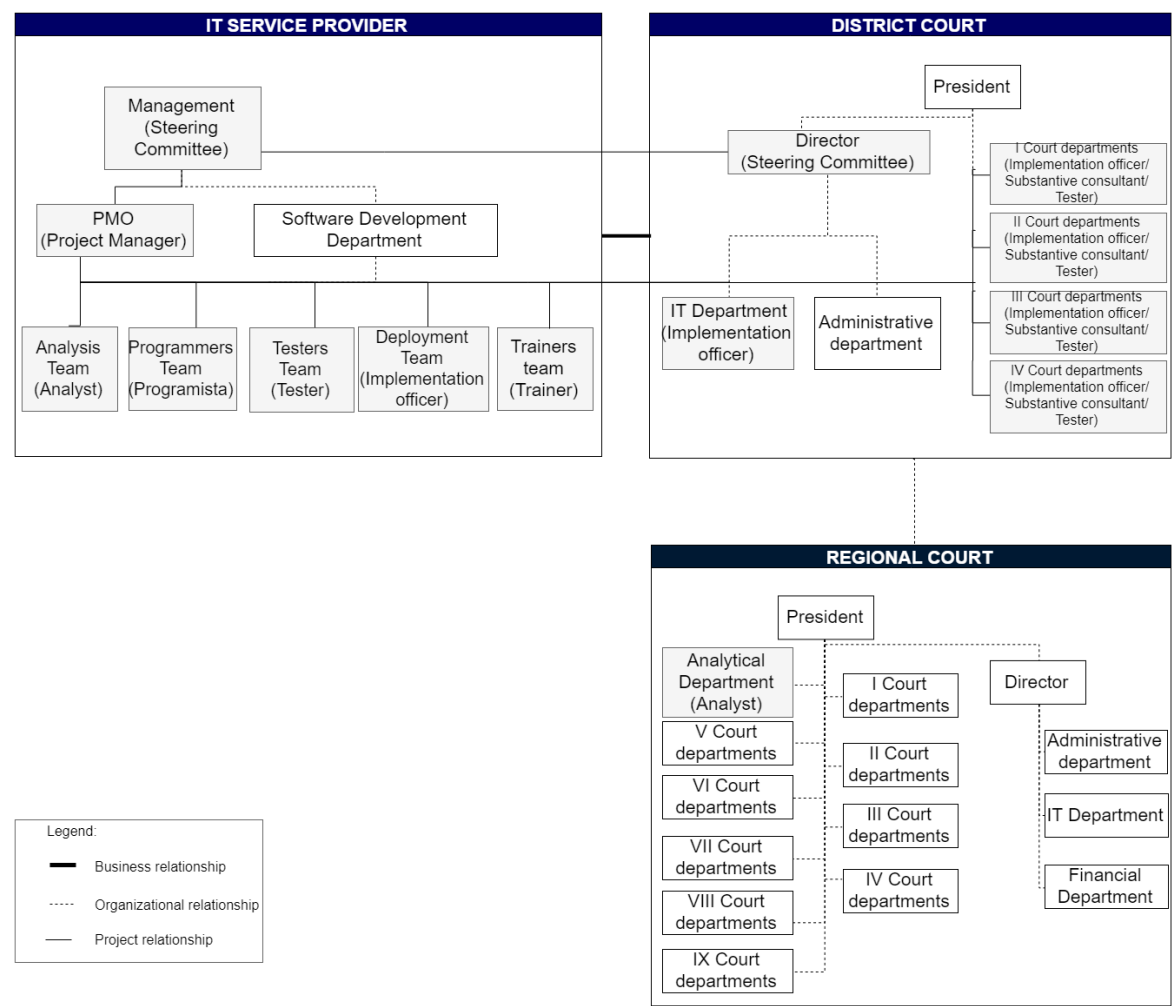

Figure 4. Project structure in organizational structure 
The project structure entities have been marked with a gray background. In addition, the relationships were included (as was the case in earlier diagrams). Although the purpose of the project was to deliver an IT solution to the district court, the identified entities are also in the organizational structure outside the court. The analysis department in the regional court is a key entity in the requirement analysis process.

\subsection{Case study - identification of processes in project}

This chapter is devoted to the identification and analysis of the processes. Based on these processes, a model is built in the next chapter. This model is described in more detail later in this chapter. The literature has many definitions of the processes that are particularly characteristic of the field. The PMI (Project Management Institute) standard defines a process as a series of successive actions that allows us to achieve a given result [12]. In addition, the authors distinguish between two types of processes: production and management. The production process (executive) consists of transforming the input elements into the intended result; in other words, it plays a direct part in creating the expected result (e.g., a product or document) [17]. In turn, management processes are oriented towards organizing the work in the project [12] (e.g., communication management).

The following model includes the identified processes that were grouped into the project stages that are typical of the Prince2 project management methodology [2]:

1) preparing the project $(\mathrm{PP})$,

2) initializing the project (IP),

3) realizing the project $(\mathrm{RP})$,

4) closing the project $(\mathrm{CP})$.

The following table (Tab. 4) lists the identified processes. For each of the processes indicated, the project stage, project type (production/management), assigned role in the project structure, description of the process, and the artifact that are the results of this process are shown.

Table 4

Project structure in organizational structure

\begin{tabular}{|l|l|l|l|l|l|c|}
\hline N & Stage & Type & Process & Assigned to & Description & Artifact \\
\hline 1. & PP & M & $\begin{array}{l}\text { Presentation } \\
\text { of the } \\
\text { solution }\end{array}$ & $\begin{array}{l}\text { Steering } \\
\text { Committee } \\
\text { (SC) }\end{array}$ & $\begin{array}{l}\text { Supplier representatives pre- } \\
\text { sented the basic functionality } \\
\text { of the solution for representa- } \\
\text { tives of the district court }\end{array}$ & - \\
\hline 2. & PP & M & $\begin{array}{l}\text { Folding } \\
\text { deals and } \\
\text { negotiation }\end{array}$ & $\begin{array}{l}\text { Steering } \\
\text { Committee } \\
\text { (SC) }\end{array}$ & $\begin{array}{l}\text { Supplier representatives have } \\
\text { prepared an offer on the basis } \\
\text { of the information obtained } \\
\text { during the presentation. } \\
\text { Following the offer, a contract } \\
\text { proposal was sent, the terms } \\
\text { of which were negotiated by } \\
\text { the parties }\end{array}$ & $\begin{array}{l}\text { Offer, } \\
\text { prelim- } \\
\text { inary } \\
\text { version } \\
\text { of the } \\
\text { contract }\end{array}$ \\
\hline
\end{tabular}


Table 4 (cont.)

\begin{tabular}{|c|c|c|c|c|c|c|}
\hline $\mathrm{N}$ & Stage & Type & Process & Assigned to & Description & Artifact \\
\hline 3. & $\mathrm{PP}$ & $\mathrm{M}$ & $\begin{array}{l}\text { Signing } \\
\text { the agre- } \\
\text { ement }\end{array}$ & $\begin{array}{l}\text { Steering } \\
\text { Committee } \\
(\mathrm{SC})\end{array}$ & $\begin{array}{l}\text { Supplier representatives pre- } \\
\text { sented the basic functionality } \\
\text { of the solution for representa- } \\
\text { tives of the district court }\end{array}$ & $\begin{array}{l}\text { Signed } \\
\text { contract }\end{array}$ \\
\hline 4. & IP & M & $\begin{array}{l}\text { Delivering } \\
\text { installation } \\
\text { package } \\
\text { and de- } \\
\text { ployment } \\
\text { documen- } \\
\text { tation }\end{array}$ & $\begin{array}{l}\text { Project } \\
\text { Manager } \\
(\mathrm{PM})\end{array}$ & $\begin{array}{l}\text { The project manager (the per- } \\
\text { son responsible for implemen- } \\
\text { ting all of the projects of this } \\
\text { solution) provided the neces- } \\
\text { sary know-how (instructions) } \\
\text { along with the tools (installa- } \\
\text { tion package) needed to com- } \\
\text { plete the design work on the } \\
\text { court side }\end{array}$ & - \\
\hline 5. & IP & $\mathrm{P}$ & $\begin{array}{l}\text { Preparation } \\
\text { of the } \\
\text { Project } \\
\text { Initiation } \\
\text { Documen- } \\
\text { tation } \\
\text { (DIP) }\end{array}$ & $\begin{array}{l}\text { Project } \\
\text { Manager } \\
(\mathrm{PM})\end{array}$ & $\begin{array}{l}\text { The document was prepared } \\
\text { by the project manager (on } \\
\text { the vendor side). The prepa- } \\
\text { ration of the document was } \\
\text { not preceded by a project } \\
\text { initiating meeting, which re- } \\
\text { sulted (for example) in the } \\
\text { lack of knowledge of the pe- } \\
\text { ople involved in the project } \\
\text { on the part of the consignee. } \\
\text { Consequently, further team } \\
\text { members were identified du- } \\
\text { ring the project. The scope } \\
\text { of the document was taken } \\
\text { from the Prince2 methodolo- } \\
\text { gy and adapted to the project } \\
\text { conditions. The DIP inclu- } \\
\text { ded the following: (i) project } \\
\text { goal; (ii) business justifica- } \\
\text { tion; (iii) project implement- } \\
\text { ation formulation (including } \\
\text { the hardware requirements, } \\
\text { description of the implemen- } \\
\text { ted solution, project scope } \\
\text { indicating the specific units } \\
\text { covered by the implemented } \\
\text { solution, and schedule). The } \\
\text { document lacked (for example) } \\
\text { the identification of roles and } \\
\text { responsibilities (project team } \\
\text { structure), project tolerance } \\
\text { describing the acceptable time } \\
\text { and cost deviations, control } \\
\text { elements, and risk register. }\end{array}$ & $\begin{array}{l}\text { Project } \\
\text { Initia- } \\
\text { tion Do- } \\
\text { cumen- } \\
\text { tation } \\
\text { (DIP) }\end{array}$ \\
\hline
\end{tabular}


Table 4 (cont.)

\begin{tabular}{|c|c|c|c|c|c|c|}
\hline 6. & $\mathrm{RP}$ & $\mathrm{P}$ & $\begin{array}{l}\text { Installing } \\
\text { the appli- } \\
\text { cation }\end{array}$ & $\begin{array}{l}\text { Imple- } \\
\text { mentation } \\
\text { officer (IT } \\
\text { depart- } \\
\text { ment on } \\
\text { the court } \\
\text { side) and } \\
\text { Deployer } \\
\text { (on the } \\
\text { vendor } \\
\text { side) }\end{array}$ & $\begin{array}{l}\text { Initially, this process was to } \\
\text { be carried out by the court; } \\
\text { however, due to the level of } \\
\text { knowledge, the IT staff was } \\
\text { implemented with considera- } \\
\text { ble support from the supplier }\end{array}$ & $\begin{array}{l}\text { Installed } \\
\text { applica- } \\
\text { tion }\end{array}$ \\
\hline 7. & $\mathrm{RP}$ & $\mathrm{P}$ & $\begin{array}{l}\text { Training } \\
\text { with solu- } \\
\text { tion opera- } \\
\text { ting }\end{array}$ & $\begin{array}{l}\text { Trainer/ } \\
\text { Court de- } \\
\text { partments }\end{array}$ & $\begin{array}{l}\text { After installation of the ap- } \\
\text { plication, training was held in } \\
\text { the district court. } \\
\text { The aim of the training was } \\
\text { to familiarize users with the } \\
\text { capabilities of the tool so that } \\
\text { they could define requirements }\end{array}$ & $\begin{array}{l}\text { Training } \\
\text { mate- } \\
\text { rials }\end{array}$ \\
\hline 8. & $\mathrm{RP}$ & $\mathrm{P}$ & $\begin{array}{l}\text { Preparation } \\
\text { of data }\end{array}$ & $\begin{array}{l}\text { Court de- } \\
\text { partments }\end{array}$ & $\begin{array}{l}\text { One of the elements of the im- } \\
\text { plementation was the ordering } \\
\text { of data from source systems. } \\
\text { Based on the generated data } \\
\text { accuracy report, the court de- } \\
\text { partments corrected incorrect } \\
\text { data and replenished missing } \\
\text { data }\end{array}$ & $\begin{array}{l}\text { Prepared } \\
\text { source } \\
\text { system } \\
\text { data }\end{array}$ \\
\hline 9. & $\mathrm{RP}$ & $\mathrm{P}$ & $\begin{array}{l}\text { Transferring } \\
\text { report } \\
\text { templates }\end{array}$ & $\begin{array}{l}\text { Analyst } \\
\text { (Regional } \\
\text { court) }\end{array}$ & $\begin{array}{l}\text { Templates were developed } \\
\text { by the regional court. The } \\
\text { district court was required to } \\
\text { provide reports in accordance } \\
\text { with the formulas provided. } \\
\text { Hence, the regional court de- } \\
\text { fined the requirements, and } \\
\text { the district court mediated the } \\
\text { transfer }\end{array}$ & $\begin{array}{l}\text { Report } \\
\text { templa- } \\
\text { tes }\end{array}$ \\
\hline 10. & $\mathrm{RP}$ & $\mathrm{P}$ & $\begin{array}{l}\text { Analysis of } \\
\text { the reports }\end{array}$ & Analyst & $\begin{array}{l}\text { The analysis of the measures } \\
\text { contained in the regional co- } \\
\text { urt reports was made on the } \\
\text { supplier's side. } \\
\text { A document containing algo- } \\
\text { rithms for the enumeration } \\
\text { measures was prepared and } \\
\text { also indicated the missing da- } \\
\text { ta from the source systems }\end{array}$ & $\begin{array}{l}\text { Document } \\
\text { with } \\
\text { specifi- } \\
\text { cation } \\
\text { of the } \\
\text { report } \\
\text { require- } \\
\text { ments }\end{array}$ \\
\hline
\end{tabular}


Table 4 (cont.)

\begin{tabular}{|c|c|c|c|c|c|c|}
\hline $\mathrm{N}$ & Stage & Type & Process & Assigned to & Description & Artifact \\
\hline 11. & $\mathrm{RP}$ & M & $\begin{array}{l}\text { Escalation } \\
\text { of the pro- } \\
\text { blem and } \\
\text { submis- } \\
\text { sion of the } \\
\text { application }\end{array}$ & $\begin{array}{l}\text { Project } \\
\text { Manager } \\
(\mathrm{PM})\end{array}$ & $\begin{array}{l}\text { Escalation of problems with } \\
\text { compliance deadlines (due to } \\
\text { the difficulty of communica- } \\
\text { tion with the court, which was } \\
\text { caused by the burden of pre- } \\
\text { paring ministerial statistics } \\
\text { and then the holiday period, } \\
\text { among others) as well as the } \\
\text { assumption of responsibility } \\
\text { for the defined requirements } \\
\text { (in the district court, the per- } \\
\text { son responsible for the requ- } \\
\text { irements was not indicated). } \\
\text { Submitting information about } \\
\text { the problems encountered in } \\
\text { the interim report. Submission } \\
\text { of the request for extended the } \\
\text { project completion date }\end{array}$ & $\begin{array}{l}\text { Interim } \\
\text { report, } \\
\text { request } \\
\text { for an } \\
\text { exten- } \\
\text { sion } \\
\text { of the } \\
\text { deadline } \\
\text { request } \\
\text { for } \\
\text { extend- } \\
\text { ed the } \\
\text { project } \\
\text { comple- } \\
\text { tion date }\end{array}$ \\
\hline 12. & $\mathrm{RP}$ & $\mathrm{P}$ & $\begin{array}{l}\text { Issue of } \\
\text { the regula- } \\
\text { tion }\end{array}$ & $\begin{array}{l}\text { Steering } \\
\text { Committee } \\
\text { (SC) }\end{array}$ & $\begin{array}{l}\text { A regulation was issued that } \\
\text { included an extension of the } \\
\text { project completion date and } \\
\text { indication of the person re- } \\
\text { sponsible for the substantive } \\
\text { responsibility for the project } \\
\text { on the court side }\end{array}$ & $\begin{array}{l}\text { Regula- } \\
\text { tion }\end{array}$ \\
\hline 13. & $\mathrm{RP}$ & $\mathrm{P}$ & $\begin{array}{l}\text { Explanation } \\
\text { and cla- } \\
\text { rification } \\
\text { of require- } \\
\text { ments }\end{array}$ & $\begin{array}{l}\text { Analyst/ } \\
\text { Court de- } \\
\text { partments }\end{array}$ & $\begin{array}{l}\text { The doubts and ambiguities } \\
\text { that arose during the analysis } \\
\text { were clarified by the analyst } \\
\text { with the staff of court depart- } \\
\text { ments }\end{array}$ & $\begin{array}{l}\text { Confirmed } \\
\text { analy- } \\
\text { tical } \\
\text { docu- } \\
\text { ment }\end{array}$ \\
\hline 14. & $\mathrm{RP}$ & $\mathrm{P}$ & $\begin{array}{l}\text { Estimation } \\
\text { of labor } \\
\text { intensity }\end{array}$ & Analyst & $\begin{array}{l}\text { Estimation of workloads for } \\
\text { implementation of reports } \\
\text { (supplement the document } \\
\text { with specification of the re- } \\
\text { port requirements) }\end{array}$ & $\begin{array}{l}\text { Updated } \\
\text { docu- } \\
\text { ment } \\
\text { with } \\
\text { specifi- } \\
\text { cation } \\
\text { of the } \\
\text { report } \\
\text { require- } \\
\text { ments }\end{array}$ \\
\hline
\end{tabular}


Table 4 (cont.)

\begin{tabular}{|c|c|c|c|c|c|c|}
\hline 15. & $\mathrm{RP}$ & $\mathrm{M}$ & $\begin{array}{l}\text { Selecting } \\
\text { reports to } \\
\text { implement }\end{array}$ & $\begin{array}{l}\text { Project } \\
\text { Manager } \\
(\mathrm{PM}) / \text { Court } \\
\text { depart- } \\
\text { ments }\end{array}$ & $\begin{array}{l}\text { Priorities have been added } \\
\text { and reports for implement- } \\
\text { ation have been selected that } \\
\text { were possible within the pro- } \\
\text { ject budget (supplement the } \\
\text { document with a specification } \\
\text { of the report requirements) }\end{array}$ & $\begin{array}{l}\text { Updated } \\
\text { docu- } \\
\text { ment } \\
\text { with a } \\
\text { specifi- } \\
\text { cation } \\
\text { of the } \\
\text { report } \\
\text { require- } \\
\text { ments }\end{array}$ \\
\hline 16. & $\mathrm{RP}$ & $\mathrm{P}$ & $\begin{array}{l}\text { Implementa- } \\
\text { tion of } \\
\text { reports }\end{array}$ & Programmer & $\begin{array}{l}\text { Data processing mechanisms } \\
\text { have been expanded with the } \\
\text { missing data needed to cal- } \\
\text { culate the measures on the } \\
\text { reports. Implementation of the } \\
\text { selected reports based on a } \\
\text { specification document requ- } \\
\text { irements }\end{array}$ & $\begin{array}{l}\text { Extended } \\
\text { ETL, } \\
\text { reports }\end{array}$ \\
\hline 17. & $\mathrm{RP}$ & $\mathrm{P}$ & $\begin{array}{l}\text { Advanced } \\
\text { training }\end{array}$ & $\begin{array}{l}\text { Trainer/ } \\
\text { Court de- } \\
\text { partments }\end{array}$ & $\begin{array}{l}\text { Training from the reporting } \\
\text { tool has been performed. The } \\
\text { effect of this training was to } \\
\text { build an exemplary report by } \\
\text { each member of the training }\end{array}$ & $\begin{array}{l}\text { Training } \\
\text { mate- } \\
\text { rials, } \\
\text { sample } \\
\text { report }\end{array}$ \\
\hline 18. & $\mathrm{RP}$ & $\mathrm{P}$ & Tests & Tester & $\begin{array}{l}\text { Verification of correctness of } \\
\text { the measures on the report on } \\
\text { the provider side (alpha-test) }\end{array}$ & $\begin{array}{l}\text { Test } \\
\text { report }\end{array}$ \\
\hline 19. & $\mathrm{RP}$ & $\mathrm{P}$ & $\begin{array}{l}\text { Acceptance } \\
\text { tests }\end{array}$ & $\begin{array}{l}\text { Court de- } \\
\text { partments }\end{array}$ & $\begin{array}{l}\text { Verification correctness of the } \\
\text { measures on the report (beta } \\
\text { tests) }\end{array}$ & $\begin{array}{l}\text { Test } \\
\text { report }\end{array}$ \\
\hline 20. & $\mathrm{RP}$ & $\mathrm{P}$ & $\begin{array}{l}\text { Improving } \\
\text { reported } \\
\text { bugs }\end{array}$ & $\begin{array}{l}\text { Analyst/ } \\
\text { Program- } \\
\text { mer }\end{array}$ & $\begin{array}{l}\text { Identification of the causes of } \\
\text { the bugs and improvement of } \\
\text { the algorithms for enumera- } \\
\text { ting measures }\end{array}$ & $\begin{array}{l}\text { Corrected } \\
\text { ETL, } \\
\text { reports }\end{array}$ \\
\hline 21. & $\mathrm{RP}$ & $\mathrm{P}$ & $\begin{array}{l}\text { Acceptance } \\
\text { retests }\end{array}$ & $\begin{array}{l}\text { Court de- } \\
\text { partments }\end{array}$ & $\begin{array}{l}\text { Verification correctness of the } \\
\text { improved measures on the } \\
\text { report }\end{array}$ & $\begin{array}{l}\text { Test } \\
\text { report }\end{array}$ \\
\hline 22. & $\mathrm{RP}$ & $\mathrm{M}$ & $\begin{array}{l}\text { Acceptance } \\
\text { of reports }\end{array}$ & \begin{tabular}{l|} 
Project \\
Manager \\
$(\mathrm{PM}) /$ Court \\
depart- \\
ments
\end{tabular} & $\begin{array}{l}\text { After another iteration of the } \\
\text { tests, the court departments } \\
\text { confirmed the correctness of } \\
\text { the measurements in the re- } \\
\text { ports }\end{array}$ & - \\
\hline
\end{tabular}


Table 4 (cont.)

\begin{tabular}{|c|c|c|c|c|c|c|}
\hline $\mathrm{N}$ & Stage & Type & Process & Assigned to & Description & Artifact \\
\hline 23. & $\mathrm{CP}$ & $\mathrm{M}$ & $\begin{array}{l}\text { Presentation } \\
\text { of the } \\
\text { solution } \\
\text { and } \\
\text { project } \\
\text { summary }\end{array}$ & \begin{tabular}{l|} 
Steering \\
Committee \\
(SC)/Project \\
Manager \\
$(\mathrm{PM}) /$ Court \\
depart- \\
ments
\end{tabular} & $\begin{array}{l}\text { After completion of the imple- } \\
\text { mentation work, a presenta- } \\
\text { tion summarizing the project } \\
\text { took place, which presented } \\
\text { the scope of the work comple- } \\
\text { ted and the planned further } \\
\text { steps }\end{array}$ & - \\
\hline 24. & $\mathrm{CP}$ & $\mathrm{M}$ & $\begin{array}{l}\text { Signing } \\
\text { of the re- } \\
\text { ception } \\
\text { protocol }\end{array}$ & \begin{tabular}{l|} 
Steering \\
Committee \\
$(\mathrm{SC}) /$ Pro- \\
ject Mana- \\
ger $(\mathrm{PM})$
\end{tabular} & $\begin{array}{l}\text { Signing of the reception proto- } \\
\text { col by the court director and } \\
\text { project manager }\end{array}$ & $\begin{array}{l}\text { Signed } \\
\text { recep- } \\
\text { tion pro- } \\
\text { tocol }\end{array}$ \\
\hline 25. & $\mathrm{PA}$ & $\mathrm{M}$ & $\begin{array}{l}\text { Presentation } \\
\text { of the } \\
\text { solution } \\
\text { in the } \\
\text { regional } \\
\text { court }\end{array}$ & $\begin{array}{l}\text { Steering } \\
\text { Committee } \\
\text { (SC)/Pro- } \\
\text { ject } \\
\text { Manager } \\
(\mathrm{PM}) / \text { Sub- } \\
\text { stantive } \\
\text { consultant } \\
\text { (SC)/Super- } \\
\text { visor of } \\
\text { Admini- } \\
\text { stration } \\
\text { (SA) }\end{array}$ & $\begin{array}{l}\text { After the end of the project, } \\
\text { a presentation was held at the } \\
\text { court supervising the court in } \\
\text { which the solution was imple- } \\
\text { mented. } \\
\text { The presentation was jointly } \\
\text { carried out by the supplier } \\
\text { and persons seconded from the } \\
\text { district court. } \\
\text { Presentations also included } \\
\text { representatives of the other } \\
\text { subordinate to the regional } \\
\text { court within the region }\end{array}$ & $\begin{array}{l}\text { Presen- } \\
\text { tation }\end{array}$ \\
\hline 26. & $\mathrm{PA}$ & $\mathrm{M} / \mathrm{P}$ & Maintenance & $\begin{array}{l}\text { IT service } \\
\text { provider }\end{array}$ & $\begin{array}{l}\text { After the implementation of } \\
\text { the termination, the agre- } \\
\text { ement provided an annual } \\
\text { maintenance period }\end{array}$ & $\begin{array}{l}\text { Reported } \\
\text { issues }\end{array}$ \\
\hline 27. & $\begin{array}{l}\mathrm{RP} \\
\mathrm{IP}\end{array}$ & $\mathrm{M}$ & $\begin{array}{l}\text { Commu- } \\
\text { nication } \\
\text { manage- } \\
\text { ment }\end{array}$ & $\begin{array}{l}\text { Project } \\
\text { Manager } \\
(\mathrm{PM})\end{array}$ & $\begin{array}{l}\text { Communication management, } \\
\text { including the assumption of } \\
\text { responsibility for the flow } \\
\text { of information on the part } \\
\text { of the district court. } \\
\text { The process lasted for the du- } \\
\text { ration of the project }\end{array}$ & \\
\hline 28. & $\mathrm{RP}$ & $\mathrm{M} / \mathrm{P}$ & $\begin{array}{l}\text { Control } \\
\text { of project } \\
\text { progress }\end{array}$ & $\begin{array}{l}\text { Project } \\
\text { Manager } \\
(\mathrm{PM})\end{array}$ & $\begin{array}{l}\text { Controlling the current pro- } \\
\text { gress of the project and, on } \\
\text { that basis, preparing interim } \\
\text { reports (weekly) }\end{array}$ & $\begin{array}{l}\text { Interim } \\
\text { report }\end{array}$ \\
\hline 29. & $\mathrm{RP}$ & $\mathrm{M}$ & $\begin{array}{l}\text { Project } \\
\text { supervision }\end{array}$ & $\begin{array}{l}\text { Steering } \\
\text { Committee } \\
\text { (SC) }\end{array}$ & $\begin{array}{l}\text { Supervision mainly on the } \\
\text { timeliness and budget of the } \\
\text { project on the basis of weekly } \\
\text { reports prepared by PM }\end{array}$ & - \\
\hline
\end{tabular}




\section{Presentation of research methods and formalization of case study}

This case study is part of the research for a doctoral dissertation. The entity of this research is the common courts in Poland. The processes and entities of the project management are the research subject. Furthermore, the methodology and scope of this research are outlined below.

The aim of the work is to build a models repository of processes and entities in IT projects for the needs of the common courts in Poland. For this purpose, the Case-Based Reasoning (CBR) method was selected. CBR is defined as an approach to solving new problems by basing decisions on experience and adapting solutions used for prior problems [14]. In the first step, the knowledge base (repository) is built, which contains the model of the entities and processes. Building this model is based on case studies. It is planned to conduct a dozen case studies that are different in terms of the scope and complexity of the project. In the wake of each case study, the model will be created by describing this case and, thus, adding a new entry to the knowledge base. As a result of this case study, the model contained in the next part of this chapter was built, which is the first entry in the repository.

In the second step, verification will be made that will consist of an attempt to use the model for a new project. In addition, it should be mentioned that the intention of the authors is to provide the model to the project manager regardless of the represented site; i.e., the court, supplier, or even another external organization. The model that will be used will be drawn from the built repository to be the best match for the new project. Then, the usefulness of the model will be determined, and the repository will be completed with the new experience [4]. The authors currently focus on the description of cases and the construction of a knowledge base. The method of evaluating the usefulness will be indicated at a further stage of the work. The above approach is presented in a diagram that reflects the CBR cycle of operation (Fig. 5).

On the basis of the identified and analyzed entities and processes contained in the chapters above, a model has been developed that addresses the processes and entities. The BPMN notation (Business Process Model and Notation) was used to build this model (which is one of the most commonly used standards for modeling the processes) [3]. In the following model, the rectangles show the processes that are associated with the linking elements. The entities and artifacts were assigned to the processes that were a result of these processes. All of the identified processes were grouped into the project stages. This case description will be introduced into the case knowledge database and will provide the basis for other cases.

The project stages typical for the Prince 2 project management methodology were used in this model (Fig. 6). All of the processes are described in Chapter 4.2. In the first stage (i.e., the preparation of the project), the process of presenting the solution, folding deals and negotiation, and signing of the agreement were identified. These processes were performed on the side of the Steering Committee. 


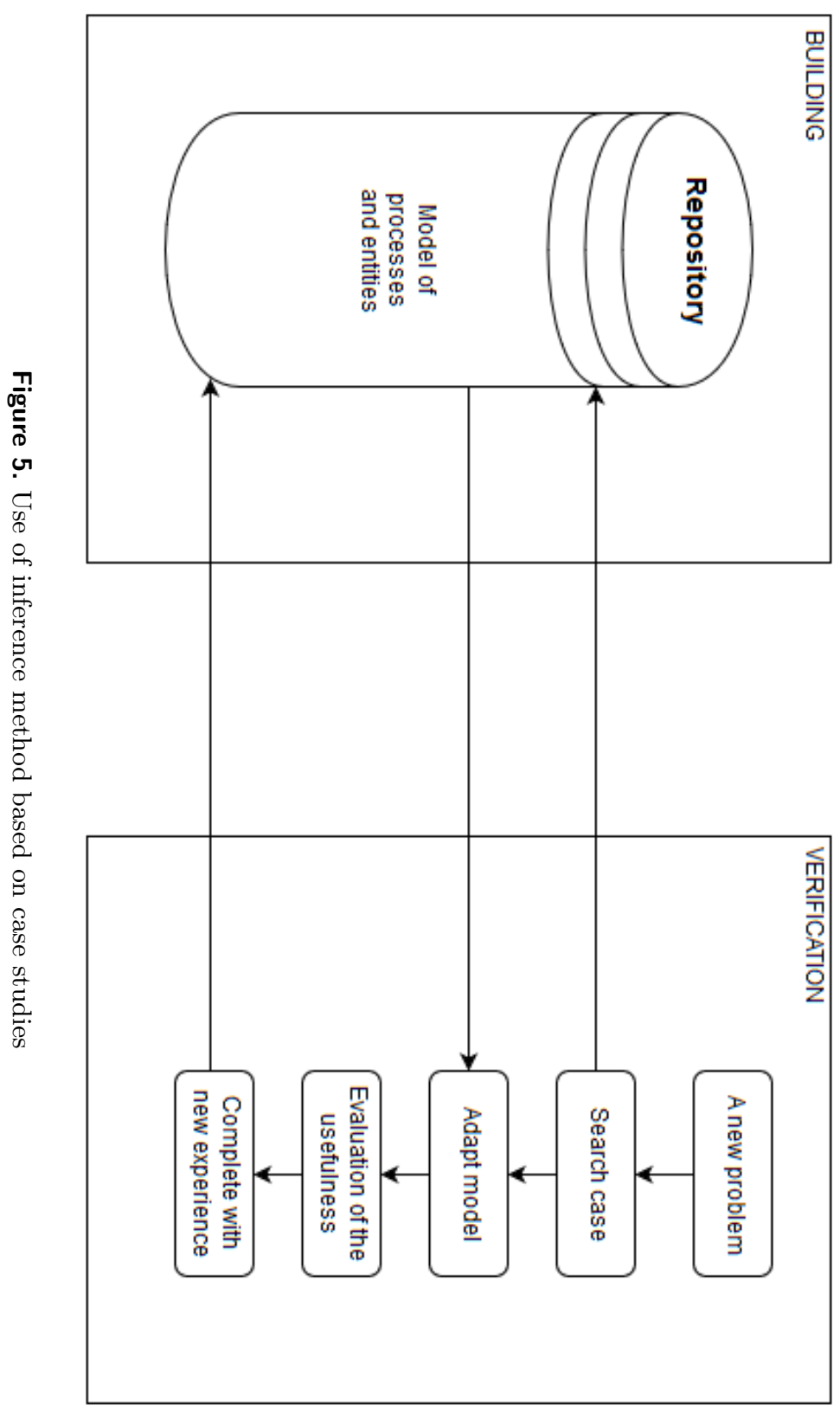




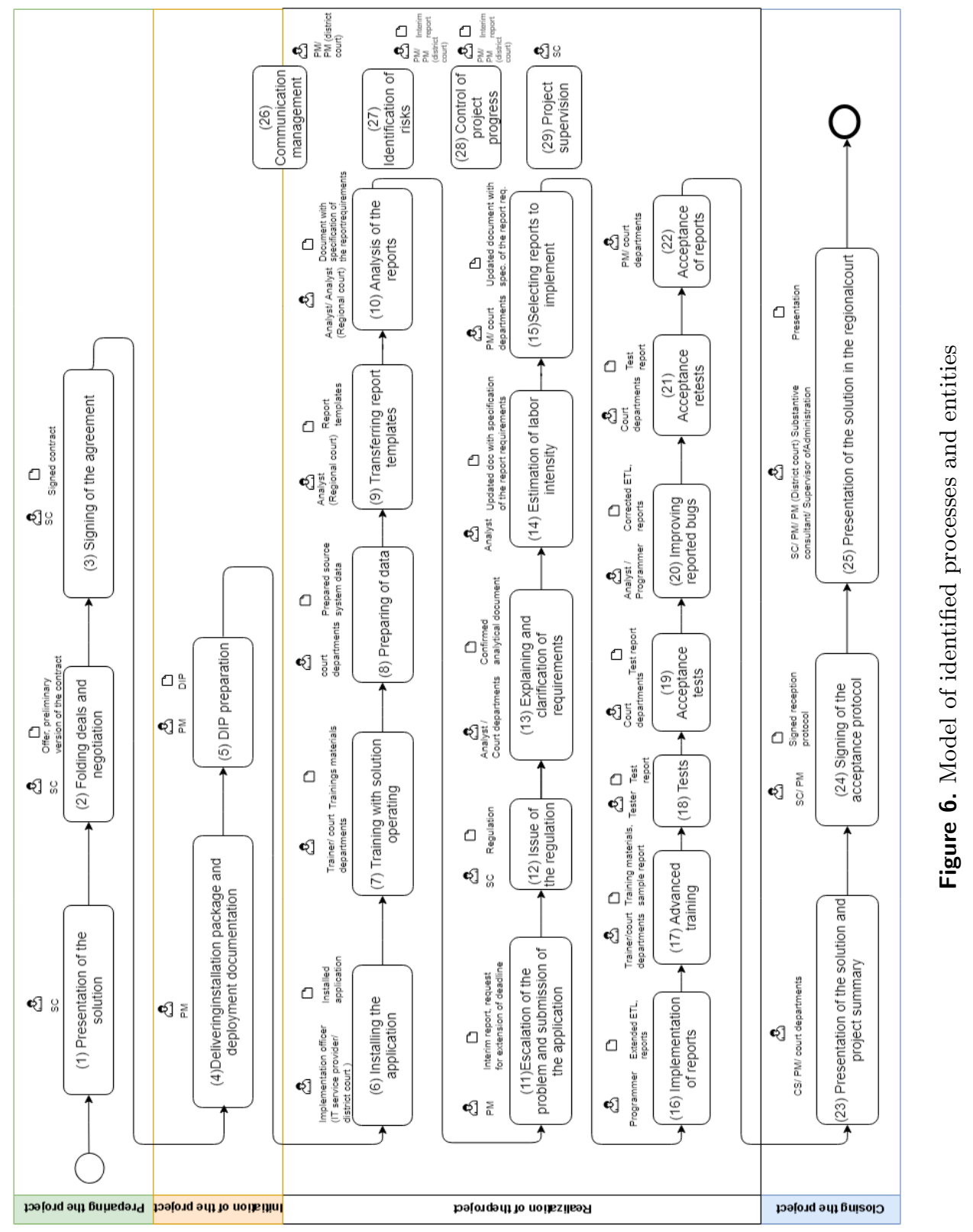


The next stage (initiation of the project) contains only two processes - delivering the installation package and deployment the documentation and preparation of the Project Initiation Documentation (DIP). The next stage (realization of the project) had the longest time horizon and covered most of the processes; i.e., all of the processes from installing the application, by preparing and correcting data in source applications, customizing the solution to individual court needs (two new reports), and training until the moment of accepting the solution (acceptance tests). At this stage, the greatest number of entities were involved (implementation officer [IT department on the court side and on the vendor side], trainer, court departments, project manager, steering committee, programmer, tester, and substantive consultant).

In the last stage typical for the Prince 2 methodology (closing the project), a meeting was organized presenting the scope of the completed works and signing the reception protocol. In addition, a meeting was organized in which all of the courts in the district participated in presenting the implemented solution and starting discussions on extending the solution to the remaining courts.

\section{Summary and conclusions}

This article attempts to adapt the available project management methods to a specific project executed in a court environment. Due to the formal requirements of running the ventures in this environment, a traditional approach was chosen based exactly on the Prince2 method.

In the realized project, the aim was achieved, i.e., the implementation of an IT system adapted to the needs of the court. Despite the aim of project achievement, several of the processes required improvement, such as ameliorating communication or increasing the involvement of the court staff (including, first and foremost, finding the time needed to implement the project). The lack of information about implementing this project in a court setting resulted in the lack of targeting the people involved in the achievement of the project's objective. Another problem was the lack of knowledge of the departmental staff about this type of solution, which resulted in the planned work on the side of the court being completed by the supplier.

At the realization of the project stage, there was also a problem with finding decision makers, even when examining the requirements. Involvement of an analyst on the side of the supervisory court would be a big facility and improvement for the project because he would define the reporting requirements for the subordinate courts. The lack of involvement of the analyst contributed to the delay in the project's implementation, which in turn resulted in increased project costs and lower project profitability. The regulation (which was issued by the court) included the period of the extension of the project and finally the identification of the person responsible for defining the requirements (substantive consultant).

The result of the case study that is the subject of the article is the construction of the model contained in the eighth chapter. Using the CBR method presented in the fourth chapter, the authors wanted to support the project management in the 
common courts in Poland by providing a model of the processes and entities. A dozen case studies are planned to be carried out, thus expanding the case repository by a dozen models. The authors intended to choose diversified projects in terms of the number of entities involved, number of products delivered, time horizon, and extent to cover as wide a spectrum of models as possible. After construction of the model, it will be verified; this will consist of finding the most similar model from the repository to the new project and using the experience and knowledge. Based on the suitability assessment and case study, the knowledge repository will be supplemented.

\section{References}

[1] Bojar W., Rostek K., Knopik L.: Systemy wspomagania decyzji. PWE, Warszawa, 2014.

[2] Great Britain. Office of Government Commerce: Prince2tm - Skuteczne zarzadzanie projektami. 2rd ed, The Stationery Office, 2010.

[3] Karkula M.: Modelowanie i zarzadzanie procesami w przedsiębiorstwie transportowym. Prace naukowe Politechniki Warszawskiej. Transport, z. 97, 2013, pp. $245-257$.

[4] Kempa A.: Modelowanie procesów biznesowych z wykorzystaniem metody Case-based Reasoning. Studia i Materiaty Polskiego Stowarzyszenia Zarzadzania Wiedza, t. 4, 2005, pp. 50-56.

[5] Kerzner H.: Project management. A Systems Approach to Planning, Scheduling and Controlling. John Willey \& Sons, Hoboken, New Jersey, 2017.

[6] Kuźmicz M., Bober B., Orłowski C., Ziółkowski A.: Zarządzanie projektami informatycznymi w jednostkach sądownictwa powszechnego w Polsce. In: Knosala R. (ed.), Zarzadzanie projektami produkcyjnymi i ustugowymi, t. 1, Oficyna Wydawnicza Polskiego Towarzystwa Zarządzania Produkcją Opole, 2017.

[7] Liebert F.: Zarządzanie projektami w przedsiębiorstwach branży IT - studium literaturowe. Organizacja i Zarzadzanie, z. 101, Politechnika Śląska, 2017, pp. 271-284.

[8] Łabuda W., Podejście zwinne a tradycyjne do projektów wytwarzania oprogramowania, Zeszyty Naukowe WWSI, vol. 9, 2015, pp. 57-87.

[9] Ministerstwo Sprawiedliwości, Informator Statystyczny Wymiaru Sprawiedliwości, 2016.

[10] Nowoczesne zarzadzanie projektami, Trocki M. (red.), Polskie Wydawnictwo Ekonomiczne, Warszawa, 2012.

[11] Prawo o ustroju sądów powszechnych. Dz.U.2016.0.2062, Ustawa z dnia 27 lipca $2001 \mathrm{r}$.

[12] Project Management Institute, A Guide to the Project Management Body of Knowledge. Project Management Institute, 5th ed., 2013. 
[13] Rasnacisa A., Berzisaa S.: Method for Adaptation and Implementation of Agile Project, Procedia Computer Science, vol. 104, 2017, pp. 43-50.

[14] Riesbeck Ch.K., Schank R.C.: Inside Case-Based Reasoning. Lawrence Erlbaum Associates, Hillsdale NJ, 1989.

[15] Strojny J., Szmigiel K.: Analiza porównawcza podejść w zakresie zarządzania projektami, Modern Management Review, vol. 22(3), 2015, pp. 249-265.

[16] Sułkowski Ł.: Czy warto zajmować się kultura organizacyjna?. Instytut Pracy i Spraw Socjalnych, Warszawa, 2015.

[17] Trocki M., Grucza B., Ogonek K.: Zarzadzanie projektami. Polskie Wydawnictwo Ekonomiczne, Warszawa, 2009.

[18] Wieczorkowski J.: Metody kastomizacji oprogramowania standardowego - aspekty ekonomiczne. Roczniki Kolegium Analiz Ekonomicznych, Szkoła Główna Handlowa, Warszawa, 2015, pp. 287-296.

\section{Affiliations}

\section{Monika Kuźmicz (D)}

Faculty of Management and Economics, Gdansk University of Technology, ul. Narutowicza 11/12, 80-233 Gdansk, kuzmiczmonika@gmail.com, ORCID ID: https://orcid.org/0000-0003-4858-4693

\section{Cezary Orłowski (i)}

Department of Applied Informatics in Management, WSB University in Gdansk,

Al. Grunwaldzka 238A, 80-266 Gdansk, corlowski@wsb.gda.pl,

ORCID ID: https://orcid.org/0000-0001-7716-5522

\section{Bartosz Bober (15)}

Currenda sp. z o.o., al. Niepodległości 703A 80-001 Sopot, bartosz.bober@icloud.com, ORCID ID: https://orcid.org/0000-0001-6010-1477

Received: 25.04 .2018

Revised: 10.09 .2018

Accepted: 10.09.2018 